\title{
Public Policy Orientations and Policy Proposals of China's Highway
}

\author{
Xianguang WANG ${ }^{1, a}$ \\ ${ }^{1}$ China Academy of Transportation Sciences, 100029, Beijing, China \\ a7731929@qq.com
}

\begin{abstract}
Keywords: Highway Public Policy, Policy Orientation, Policy Recommendation.
Abstract. The highway transportation in China has undergone development courses from "bottleneck restriction" to "general alleviation" and then to "basic adoption". And future-oriented appropriate development has been realized in some fields. By the end of 2016, the total distance of highways in China was 4.6963 million $\mathrm{km}$, which was increased by 4 times compared with the total distance of $890,000 \mathrm{~km}$ in 1978 . With the concept connotations of public policies and the basic attributes of highways, this paper discusses the laws of function that must be followed by highway public policies based on the explication of the connotations and classifications of highway public policies. And then the demands and environment of the formulation of highway public policies in China are analyzed. In particular, the development orientation of highway public policies in China as well as recommendations is proposed.
\end{abstract}

\section{Introduction}

Taking a retrospective look at the development history of over 30 years of the highway transportation in China, great-leap-forward developments have been achieved [1]. Such achievements benefited from the policies of various types on highway development by central and local governments, which have played an important role in driving economic and social developments. Highway public policies are choices made by decision makers on highway construction, maintenance and sustainable development. The formation of related highway public policies by national decision maker to boost fast and healthy highway development is under the premise of balancing the costs and profits of the formulation and implementation of highway public policies [2]. This paper discusses some key issues in the formulation of public policies of future highway transportation in China.

\section{Concept Connotations and Features of Public Policies}

Public policies refer to the political actions or rules of conduct adopted by state organs, the ruling party and other political groups during a given period to achieve or serve certain social, political, economic and cultural goals. It is the general term of a series of strategies, laws, measures, methods, methods, conditions, etc. The main features are as follows.

(1) The main body of public policy is mainly the government. Due to the particularity of public policy, the main body is mainly government. Only the government has the authority to apply a defined public policy in a specific region or the whole country.

(2) The object of public policy is the distribution and adjustment of public interests. Generally, public policies are required to be balanced among various conflicts of interests to ensure the smooth implementation of public policies and steady social developments. Such conflicts of interests may manifest primarily or ultimately as conflicts of economic interests.

(3) The specific forms of public policies are the various laws, decrees, plans and programs formulated by the government. Public policies are generally expressed as government intervention or non-intervention (inaction) in social and economic life. The government must formulate corresponding laws and regulations in advance so as to adjust the relations among the various stakeholders.

(4) The goal of public policies is to maximize the public interests. The general principle of economics shows that the goal of "economic men" is to maximize the own interests, which will achieve the state of "Pareto Optimality" of parties involved in the transaction in a freely competitive 
market, while the goal of the "Pareto Optimality" state to be formulated and implemented through public policies is to maximize the social public interests [3].

(5) The formulation and implementation of public policies requires the supports of corresponding public policy resources. There is also actually a cost-benefit comparison issues for public policies.

\section{Definition of Highway Public Policies}

\section{Basic attributes and public policy orientation of highways}

The basic attributes of the highway reveal the nature and characteristics of the highway as an economic activity to participate in social economy operation. The different public policy orientations are determined by its natural monopoly, quasi-public product attributes, product attributes, externalities, etc.

(1) Orientation of public policy based on natural monopoly and commodity - Introduction if competition

Break the market blockade and introduce a reasonable mechanism of competition. To satisfy the requirements of open competition of highways, various measures must be taken to encourage social capitals to enter the highway industry and vigorously promote market-oriented construction of investment and financing activities in monopoly industries.

Combine incentives and constraints, and strengthen the effective supervision on the highways. For highway construction, operation and management, it is necessary for the government to adjust the relations among industry-related operators, consumers, investors and governments by means of legislation and administration.

Seek for new alternatives on regulation. As an industry of natural monopoly nature, the government should give full consideration to choose different regulation methods in combination with the development stage of the industry as well as the macro international and domestic backgrounds in the formulation of public policies.

(2) Orientation of public policy based on the quasi-public product attributes - Privatization

To solve the problems of inefficient construction and management, power rent-seeking and high construction fund shortage in highway development, it is necessary to make full use of the quasi-public product attributes to promote the privatization of highways, including modes such as franchising and PPP.

(3) Orientation of public policy based on externality - National taxation and integration planning

According to the theory of public goods management, the huge capital investment and externality of highway and land use integration planning determine that the highway is an important part of regional economic and social development. The primary task of regional economic and social development is making appropriate regional planning. Highway constructions add public values to the lands along the highways, while the added values of land further promote the development of the highways.

\section{Connotations and classifications of highway public policies}

According to the definition of public policy and the characteristics of road traffic, this paper defines public policy of highway transportation as adopted political activities or prescribed codes of conduct by the government to achieve fairness, efficiency, and democracy, healthy and sustainable development of highways within a specific period of time. It is a general term for a series of management measures, methods, means and regulations concerning highway construction and maintenance.

At present, the policy system of public transportation policy in China includes two aspects: public policies at the national level and public policies at the industrial level [4]. Public policies at the national level are developed mainly based on the macroeconomic environment of the country. However, such policies have profound impacts on the development of highway transportation. The 
public policies at the industrial level mainly include various policies such as the policy-based subsidiary policies, preferential policies, capital policies, technical policies, conservation policies, human resources policies, management policies, supervision policies, and reward and punishment policies as well as sustainable development policies. Such public policies have played an important role in promoting highway construction and development, strengthening highway management and maintenance, ensuring the smooth highway operation and better serving the economic and social development. The manifestations of public policies mainly include the policies of the Communist Party of China, the legislation of the People's Congress, the administrative decisions of the state administrative organs and the judicial interpretation of the national judicial organs as well as manifestations making systematic sorting of the highway transportation.

\section{Features of public policies on highway transportation}

(1) Integrity and extensiveness. After the implementation of a public policy, it must inevitably affect the highway development of the entire area or the country, and adjust all aspects of the entire social and economic life thereof. The integrity of public policy also shows that various kinds of public policies complement each other and form a complex that is interrelated, mutually reinforcing and mutually influential. Meanwhile, as public policies on highways are generally formulated and implemented in response to a specific problem, different public policies on various social and economic issues are required be formulated and coordinated, giving the feature of extensiveness of and public policies.

(2) Legality and compulsoriness. The manifestations of highway public policy are generally the laws and regulations regulated and promulgated by the state (the government) with compulsory forces, which reflects the legitimacy of public policy itself, and it is also an authoritative guarantee for public policy. Due to the differences and complexities of public interests, to safeguard the legitimacy and authority of public policies so that they can be effectively implemented and implemented, public policies must be mandatory.

(3) Stability and changeability. As the means for government to perform its own functions as well as a tool for social public administration, highway public policies must be kept stable. As a matter of course, the premise of stability is that public policies must be correctly formulated and effectively implemented. Only in this way can the continuity and seriousness of public policies be guaranteed. While maintaining the stability requirements, consideration must be given to the variation of social public interests so as to adjust their own compositional elements, that is, the changeability requirements of public policies.

(4) Fairness and efficiency. Highway public policies is the way and means for public administration by public agencies such as the governments. To maximize the public interests in public administration of the government, to some extent this fundamental goal is expressed as the realization of social fairness and justice. While pursuing the maximization of public interests, efforts are also required to reduce expenditures as much as possible and try the best to achieve the goal of "Less Input, More Work and Greater Benefits".

\section{Analysis on Environments of Highway Public Policies in China}

(1) The overall goal of building a well-off society in an all-round way brings forward specific requirements on highway development in China during the "Thirteenth Five-Year Plan".

The basic goal of a well-off society is to enable more prosperous people's livelihood, more convenient travelling and better living conditions. Constructing a modern, comprehensive transportation system that is safe, convenient, green, economical and efficient is an important part of building an overall well-off society. At present, more than $80 \%$ of passenger traffic volume and more than $75 \%$ of the freight volume in China are undertaken by highways. And highway is still the absolute mainstay of China's passenger and freight transportation and has a crucial impact on the pioneering role of transportation in national economies. Therefore, to accelerate the construction of the highway transportation network that is "safe, reliable, convenient and efficient, green and smart 
with high quality services" is an inevitable requirement for serving and supporting the overall goal of building a well-off society in an all-round way.

(2) Technological innovation and industrial transformation provide the powerful impetus to highway development in China

China's highway infrastructure and transportation network has preliminarily taken shape, providing basic conditions for the shifting from an "Extensive Transportation Country" to an "Intensive Transportation Country". Great supports for the highway transportation upgrading of promoting quality and enhancing efficiency are lying in the promotion of the implementation of the "Internet + Convenient Transportation", "Internet + Efficient Logistics", the acceleration of the process of building smart traffic as well as the promotion of a new generation of information technology and organic highway transportation integration. These are also effective means to modernize highway transportation.

(3) Serving and supporting the national major strategies is an important task for the highway development in China

To coordinate the development of the "four major sectors", efforts are required to speed up the improvement of transportation conditions in the western regions under the guidance of mid- and long-term highway planning at all levels, accelerate the smooth development of highways in the northeast and central regions and support the modernization in the eastern region in light of the phased characteristics of different regions. To implement the Belt and Road strategy, efforts are required to strengthen the construction of a major thoroughfare for international transportation and realize the interconnection of domestic and foreign channels. To promote the coordinated development of Beijing, Tianjin and Hebei, efforts are required to take the lead in the breakthroughs of transportation integration. And to promote the development of the Yangtze River Economic Belt, efforts are required to optimize the capacity allocation of integrated three-dimensional large thoroughfares, improve inter-city traffic network of urban agglomerations, and play a leading role of highway transportation in optimizing urban spatial structure, fostering a new economic growth poles and expanding regional development spaces.

(4) The golden period of transportation development has brought great opportunities for the highway development in China

The highway is an important part of integrated transport and presently takes the leading position in the transportation system in China. The structural optimization of the highway network ushers in new opportunities. And there are still many weak links in the highway infrastructure in the central and western regions, especially the former revolutionary base areas. It is urgently needed to increase input and make up for shortcomings. The transformation and upgrading of highways ushers in new opportunities. And industry reform and technological innovation provides core impetuses for the highway development during the 13th Five-Year Plan period. Efforts will be made to accelerate the construction of highways, give priority to the construction, maintenance, transportation and management and open up a new space for highway development.

\section{Highway Public Policy Orientations and Recommendations}

\section{Policy orientations}

The promulgation of public policies in any industry necessarily includes the strategic choices as well as the values of the policy subjects. This is also applicable for highway public policies. The government, as the main decision maker of highway public policies, is the largest holder of public powers. Therefore, the greatest difference between the public policies and the general policies is embodied in the word "public". Publicity is its most essential attribute. Specifically, the orientations of public policy on the highway mainly include the following aspects.

(1) Fairness

The value orientation of public policy naturally implies social equity and the primary value orientation of public policies of highways is also fairness. To regard fairness as the value orientation 
of highway public policies, the governments should fairly treat every party involved in the formulation and implementation of public policies. This mainly involves two aspects: First, from the perspective of the participants in the market, highway policies should create equal opportunities for competition among enterprises. Second, from the perspective of traffic participants, the highway policies must take into consideration the two systems of toll highways and non-toll highways so that travelers have the freedom to choose.

(2) Efficiency

Efficiency, as the value orientation of public policy, mainly refers to the effectiveness of policy resource allocation. Highway public policy is also the effective allocation of national policy resources. It is through the formulation and implementation of highway public policies that a nationwide high-quality highway network is basically established to make the people's trips safer, more convenient and more comfortable. So that the highway can basically meet the overall requirements of building a well-off society in an all-round way and gradually narrow the gap with Pareto Efficiency. This fully reflects the efficiency orientation of rural highway public policies. The efficiency orientation of highway public policies is mainly manifested in two aspects: one is the rational allocation within the region; and the other is the rational allocation of the structure.

(3) Democracy

The democratic value orientation of highway public policy should also reflect the public nature, legitimacy and openness. In the formulation and implementation of policies, the public should be engaged to enable their rights to speak, to know, to participate and to supervise. Due to its basic nature and public goods character, highway public policies should reflect the value orientation of democracy and serve the broad masses of people.

(4) Orderliness

The purpose of formulating and implementing highway public policies is to speed up economic development, safeguard social stability and create a good order and environment for the entire social and economic development. The orderliness orientation of the highways is mainly manifested in two aspects: First, to maintain regional stability; second, to promote national unity.

\section{Policy recommendations}

(1) Deepen the reform of the powers and responsibilities in the field of highways and clarify the powers and responsibilities of the transportation departments at all levels

Fiscal power is the task and responsibility that a government should undertake to provide basic public services with financial funds. Expenditure responsibilities are the obligations and guarantees for the government to fulfill fiscal expenditures as well as the preconditions and basis for the government to formulate public policies. In the new stage of development, there are still problems of unclearness, unreasonableness and non-standardization. The main manifestations include: The functional orientation of the government and the market is not clear enough; the financial rights and expenditure responsibilities of central government and local governments are not clear, and there are more issues to be shared between the central government and local governments, etc. Therefore, promoting the reform of the division of fiscal powers and expenditure responsibilities between the central and local highways authorities is the precondition and basis for enhancing the pertinence and effectiveness of highway public policies.

(2) Adapt to the trends of state finance and taxation reform and improve the highway investment and financing policies

First, make good use of investment and financing policies with central special funds on transportation. In accordance with the requirements of the central government to optimize the transfer payment structure and standardize the special transfer payment and in combination with the scope of the central authority as determined by the reform of the powers and authorities, more special funds such as the vehicle purchase taxes should be used for key projects such as national expressways, integrated passenger and cargo transportation hubs. Second, properly work on the stock of highway debts, improve road bond policies. For local toll roads, local governments are encouraged to replace existing debts by means of special bond issuance; for non-toll roads that bearing no returns, non-toll 
road debts should be included into local government general bond budgets as public welfare infrastructures. Third, standardize the highway PPP projects and promulgate detailed implementation rules as soon as possible so as to guide all localities to effectively promote the implementation of PPP projects.

(3) Accelerate the construction of "Two Highway Systems" and improve the road pricing policies

First, straighten out the management system and mechanism and readjust the laws and regulations, and gradually establish the toll highway system with the expressways as the main body and the non-toll highway system with the ordinary highways as the main body by consummating the highway development plans. Second, explore effective institutional mechanisms for toll highways in accordance with the principle of "diversified investment and unified management" so as to protect the enthusiasm of investors, safeguard their legitimate rights and interests, and ensure the safe and efficient operation of the highway network. Third, establish a sound highway management system to maximize the benefits of limited funds in accordance with the principle of unified management and stratified responsibility.

(4) Promote the transformation of highway maintenance and improve the highway maintenance policies

First, work on scientific conservation decision-making. Strengthen technical supports for the formulation of highway maintenance policies and improve the scientific and democratic decision-making level through information technology means. Second, promote the systemization of the maintenance and management system. Amend the Administrative Measures on Highway Maintenance Projects and improve the maintenance project management systems as soon as possible. Improve the maintenance management budget, supervision and evaluation systems and formulate the toll highway service quality evaluation standards and service rating systems.

(5) Adhere to the concept of green development and strengthen the policy orientation of sustainable highway development.

First, the development mode of highway transits from the scale and speed oriented to quality and benefit oriented. To adapt to the requirements of the New Normal development, the development of highway transportation should be emphasized on not only the scale but also the quality. It is necessary to guide the construction of the highway network more scientifically and rationally and to enhance the overall performance of the highway network through planning and coordination with the concept of overall coordination. Second, the development mode of highway transits from resource-intensive to resource-saving. In the planning, construction, operation, service and management of highway transportation, formulate practical and reasonable plans for the rational and effective use of resources so as to establish a benign mechanism for coordinated development of transportation and resources. Third, the development mode of highway transits from ecologically-disruptive to ecologically-protective. In the policy design and formulation stage, systematic environmental impact assessment of policies should be conducted to promote the harmonious integration of highway construction into natural ecosystems and achieve a deep integration thereof.

(6) Adhere to the concept of military and civilian integration and strengthen the military support capability of highway transportation

First, amend the relevant standards of highway infrastructure. On the basis of the existing highway infrastructure construction standards for highways, service areas, etc. give full consideration to the needs of military weapons and equipment to revise and consummate such standards in accordance with the principle of combining peace and war so as to promote the integration of civil and military highway and transport infrastructure.

\section{References}

[1] L. C. Li: How Many Railways and Highways Are Required for China? (China Planning Press, Beijing 2015).

[2] X. W. Gao, in: Public Policy Evaluation: System and Process, Public Administration Vol. 2 (2008), p. 58-62. 
[3] T. X. Chen, in: Indicating System for Governmental Performance Measurement: Designing Methods, Journal of Wuhan University Vol. 1 (2008), p. 82-87.

[4] Z. M. Chen: Analysis on Public Policies (China Renmin University Press, Beijing 2002). 